\title{
RHETORIC IN VISUAL ARABIC POETRY: FROM THE MAMLUK PERIOD TO THE DIGITAL AGE
}

\author{
Dr. Eman Younis
}

\begin{abstract}
Rhetoric has been of great importance in philosophy, criticism and literature since Aristotle, through the Golden Age of Arabic studies and down to modern literary trends. Rhetoric is tightly bound with literary texts in all their manifestations and artistic, literary and analytic gradations. There are three aspects of rhetoric in every literary text of whatever type. One of these has to do with content, that is, with the author's ability to convince the receiver by alternately addressing his mind through logic and proofs and his heart by arousing in him feelings of desire and dread. This aspect of rhetoric is know in Arabic as 'ilm al-bayān (rhetoric in the strict sense). Another aspect concerns style, that is, a writer's ability to manipulate words and create novel linguistic modes through the use of metaphors, similes and other devices, which in Arabic is called 'ilm al-badí' ("the science of metaphors and good style"). The third aspect concerns form, that is, the text's structure, its forms and icons. This is known as al-balāgha al-bașriyya ("visual eloquence"). Although there are various distinct types of balāgha ("eloquence, good style, rhetoric in the general sense"), they all have one purpose, namely to affect the receiver in some way. The present study focuses on the manifestations of visual rhetoric in visual Arabic poetry and on the way literary criticism has dealt with it. Visual poetry as it is known in the literary sciences refers to those aspects of poetry which go beyond language and content, such as a poems basic form and external structure. These manifestations of rhetoric are derived from the relationship between form and content in order to generate meaning and affect the reader. The present study will focus on the manifestations of visual rhetoric in Arabic visual poetry and their evolution from the Mamluk period down to the digital age.
\end{abstract}

KEYWORDS: Visual Rhetoric. Visual Poetry. Digital Poetry. Digital Rhetoric.

\section{Visual Arabic Poetry: beginnings and formation}

Interest in the technical form of the traditional Arabic poem (qașida) first arose when poetry made the transition from the oral to the written stage. During the former the main focus was on content and the stylistic elements that contributed to producing a pleasing effect on the ears. Qașidas were filled with metaphors, allusions, similes and utterances that produced an auditory effect on the receivers and aroused their fervor. A poem's eloquence was thus judged by the poet's ability to create new imagery and an original style in which contrasts, paronomasia, metaphors and other devices were used to arouse the receiver's feelings and stimulate his mind. Eloquence has thus been closely associated with pronunciation, giving pleasure to the ear (ABŪ KHADRA, 2007, p. 6). The concept of rhetoric remained basically 
focused on spoken style until poetry made the transition from the oral to the written stage, from being focused on the listener's ear to being focused on the reader's eye instead. Poetry then became a printed entity, which was seen before it was heard.

The beginnings of this change took place during the Abbasid period, when the qașida came to occupy a new spatial form and a new semiotic form, due to the growing awareness of the value writing as well as the materials and prerequisites of writing, in line with the spirit of an age that saw an increasing interest in the decorative arts, mosaics, building construction and sculpture within the edifice of Islamic art.

However, the visual processing of poems at the time was limited to decorative modifications of the Arabic script, with no rhetorical objectives. Thus stanzas and verses on mystical love were transformed into visual pictures and icons that were used for the embellishment of the outer walls and inner surfaces of mosques, palaces, courtyards and the like (fig. 1), placed so that they contributed to the symmetry of the structure's decoration (AL-WARĀRĪ, 2014).

Fig. 1 - Sculpted verse on a palace wall.

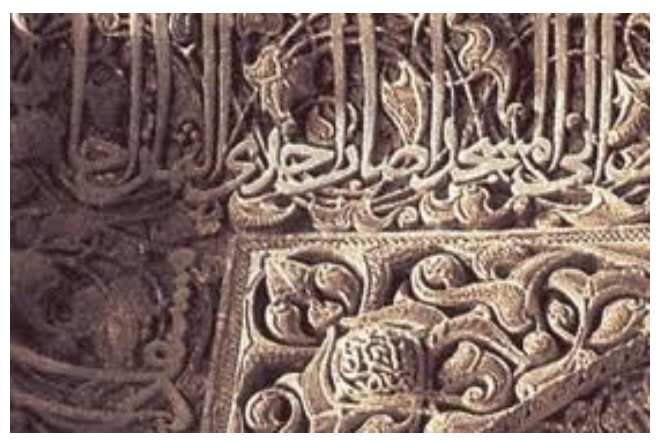

In the Mamluk period poets took the qașida in new directions, using novel poetic techniques of a more cultured character. The new poetry focused on embellishment, decoration and plays on form. This development constituted a qualitative change of course in the history of the composition of poetry and heralded the beginning of a new phase, in which the rhetoric of poetry moved from acoustic to visual formation and revealed a surprising ability among poets to enhance a poem's rhythm and to give it visual substance. 
The critic Kamāl Abū Dīb in his book Jamāliyyāt al-tajāwur (The Esthetics of Adjacency; 1997) argues that the roots of this visual poetry go back to the twelfth century CE, when the Arab poet al-Jalyānī al-Andalusī al-Dimashqī produced a work that was unprecedented at the time, a collection of poems entitled al-Tadbij (Adornment), in which "al-Jalyānī created a pioneering model for what has become known as the interweaving of creative spaces. He invented a unique structure in which color, script, form and language resonate with each other and transformed language from a purely acoustic phenomenon to one that has a visual dimension as well, thus enabling poetry, which until then only presented and imitated, to become unadulterated formation in the modern sense of the word (ABŪ DĪB, 1997, p. 77).

Muḥammad Najīb al-Talāwī in his book al-Qașīda al-tashkīliyya fĩ al-shi 'r al-'arabī (The Visual Qașida in Arabic Poetry; 1998) provides numerous examples of Arabic visual poetry and also discusses the various names that critics have given to poems of this type. Some are "geometrical poems" because of their physical forms, such as a circle (fig. 2), a triangle (fig. 3), a square, a pentagon or a rhomboid (fig. 4). Others are called "drawn poems" because they are printed in the shapes of flowers, birds and the like, while still others are called "tree poems", for obvious reasons. However, the more general term used by Arab critics has been "visual poetry" (al-shi'r albașarî), because it uses visual form as a substitute for verbal expression. Al-Talāwī proposed the term al-shi'r al-tashkili (literally: "plastic poetry") because of its universality and its ability to encompass the various levels of artistic endeavor (ALTALĀWIT, 1998, pp. 14-28). In the West literary critics have used terms such as "calligrams" and "concrete poetry" to denote visual poems (DI ROSARIO, 2011, p. 47). 
Fig. 2 - Poem in the shape of a circle, Mamluk period.

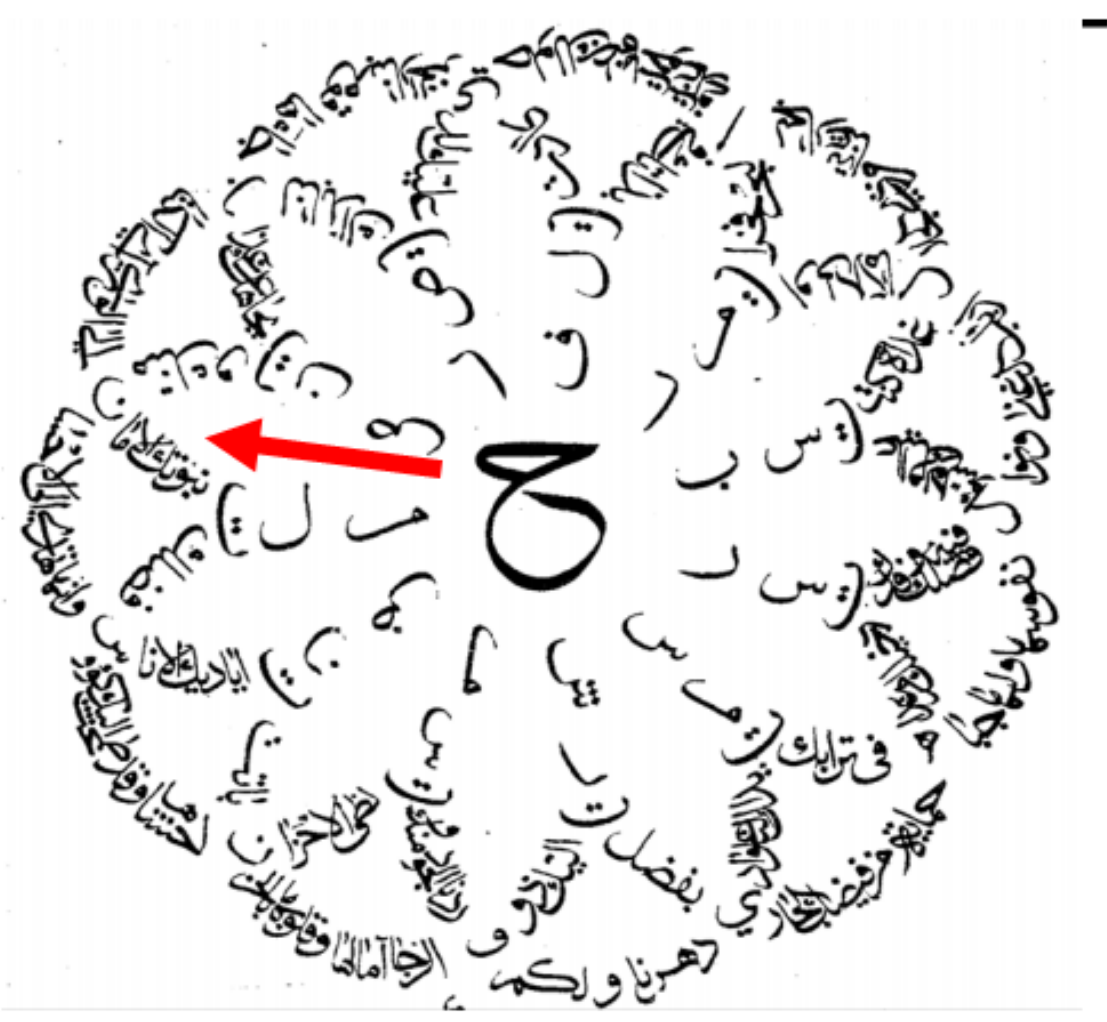

Fig. 3 - Poem in the shape of a triangle, Mamluk period.

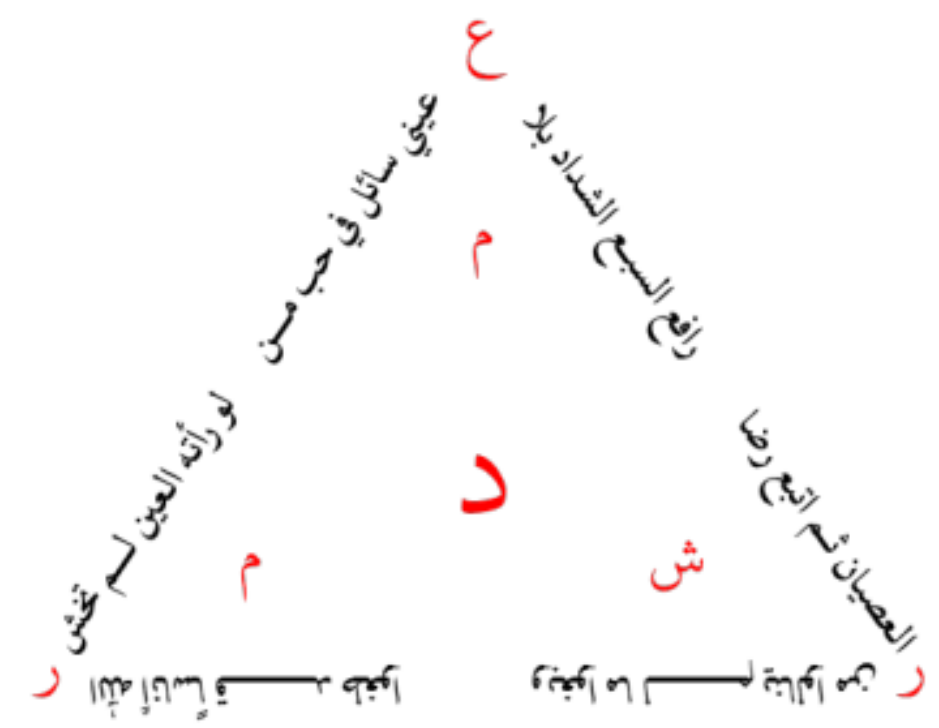


Fig. 4 - Rhomboid shaped poem.

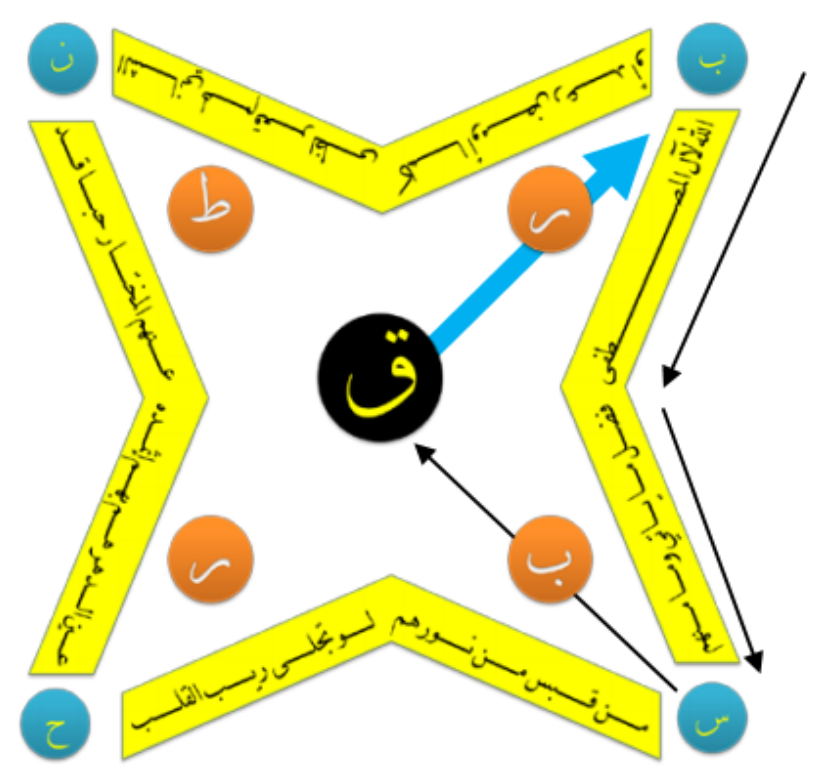

The critic Fāḍil Yūnus Ḥusayn in his article "Jamāliyyāt al-qașīda al-handasiyya byna al-wāqi wal-țumūḥ" ("Esthetics of the Geometrical Poem: between Reality and Aspiration") mentions another type of geometrical poem that was composed by Arabs in the Mamluk period, a type that he calls "pseudo-geometrical". He divides these into a number of different kinds, among them al-muhmil ("heedless") in which the letters appear without diacritics, al-mu jam ("diacritical") in which all diacritics appear, almulamm' ("polished"), al-arqaț ("speckled") and others (HUSAYN, 2012).

Husayn argues that the purpose of visual poetry at that time was to highlight a poet's prowess by showing, first of all his great poetic aptitudes and, secondly, his ability to compete and disable others (ibid.). This means that the rhetoric of visual formation for these poets was restricted to what is called 'ilm al-badī' ("the art or science of good style"). However, this "good style" referred to visual elements and not to the aural elements that one expects. Nor did the poets try to bond their poems' geometrical form with their contents. As a result, literary critics at the beginning of the Arab Renaissance period viewed this poetry as inferior and in fact ignored. Indeed, visual poetry during both the Mamluk and the Ottoman periods suffered from an undeservedly bad reputation. Both Arab critics and Orientalists declared that this was 
a period of decline and fragmentation, a period whose literature was accused of paralysis and feebleness (AL-WARĀRI, 2014) because the poets focused their interest exclusively on content and style, and considered everything else to be mere externals. The reason for this is that the concept of rhetoric in critical theories remained for a very long time restricted to the spoken or the acoustic, while the visual dimension began to be deemed an aspect of rhetoric only very late. To this we must add that the critics themselves did not possess the tools for visual criticism at that time (FOSS, 2011).

\section{The visual poem in modern times and the concept of rhetoric}

Towards the end of the first half of the last century a generation of Arab scholars emerged that did justice to visual poetry and acknowledged its qualities. They re-read the poems in light of modern critical theories, using the tools of visual criticism borrowed from the various plastic arts and Western critical movements. During the Renaissance theories of "ideal esthetics" were dominant. These called for basing the homological and allegorical balance of its structures on the plastic arts and on architecture. Anything that deviated from these laws was not taken into consideration, until the advent of the Baroque period at the end of the sixteenth century, when philosophers, architects, artists and poets rebelled against the laws of Renaissance art and literature. Baroque architects used the geometry of curved surfaces and forms that contradicted the plastic arts that were dominant at the time. As a result the Baroque style adopted an ideological social approach in which the separation between mind and spirit was rejected, contrary to the philosophical approach of the Cartesian school. Baroque art was characterized by a divergence of forms, that spanned the gamut from aristocratic embellishment to works of art that fit the popular taste. Baroque philosophy also showed a mixture of emotion, material and movement, reflected in both art and poetry (NAȘR ALLĀH \& YŪNUS, 2015).

The most momentous change that West European civilization underwent as a whole, one that affected its art and literature, came in the wake of World War I. The outbreak of that war influenced minds of writers and artists, who were disappointed with the 
philosophical underpinnings of the Western theories of esthetics at the time. As a result four revolutionary artistic movements that called for doing away with fixed criteria in the arts appeared at the beginning of the twentieth century: Cubism, Futurism, Surrealism and Dadaism. All of these movements emerged at about the same time, so that one style became intertwined with the others. Some artists who belonged to one of these movements thus also created works in one of the other, similar styles, due to their intellectual and temporal affinity (DI ROSARIO, 2011, pp. 49-60).

Arab critics benefited from these movements, which they used in the analysis of Arabic literature. This was true especially of visual poetry, which attracted their attention from its very beginning. These critics revealed the rhetorical elements hidden in the poems' form and geometrical structure, which required no less skill than that needed for the creation of linguistic and semantic innovation. Among these critics we may mention Muhammad Banyas, whose education in the plastic arts enabled him to understand the visual dimension that characterized some of the poetic experiments in which poetry and script were combined into beautiful poems that were also visually pleasing. In his book Zāhirat al-shi 'r al-mu'āșir fĩ al-Maghrib (The Phenomenon of Contemporary Poetry in Morocco; 1985) Banyas provides a brief depiction of the way in which early and later poets in Andalusia and Morocco dealt with the structure of place in the formation of poetic texts. He notes that Arab calligraphers devoted much effort into the formation of poems and took care to take into consideration the specific characteristics of the formation of place in the poem. In this situation the composition of the text is subject to formational laws that made it possible of ancient Arab poets, especially those who were able to write out their poetry collections or to supervise their production, to imbue them with their artistic feelings (BANYAS, 1985, pp. 97-99).

Another critic who called for paying attention to a text's visual space and argued that form and content must not be detached from each other was the Syrian-Lebanese poet Adonis, who wrote: 
The way something is said is more important than what is said. The new artistry is a most important element of poetics and a poem's form is the entire poem, a language that cannot be separated from what it says, and a content that is not separate from the words which express it. From and content are thus a unity in every true work of poetry (ADONIS, 1978, p. 15).

Adonis stresses the importance of the visual aspect in any poem whatsoever. He notes that content alone, without taking form into consideration, or the converse, mean the death of the poem, whose rhetoric is impossible to understand in this way.

As time went on ever more types of poem were attempted, with various kinds of visual elements, as evidenced by the muwashshah (poetry arranged in stanzas), the zajal (strophic poetry) and taf'ila (metric) poetry. Modern criticism has continued to focus on the visual dimension of poetry, which it considers to be part of its rhetoric, one that if ignored can lead to a disintegration and loss of its meaning.

Experimentation in the field of visual poetry has continued to this day, indicating that poets do indeed believe in the artistic value of the visual element in their poems and in its effect on the receiver. Thus, for example, a number of contemporary Palestinian women poets turned their works into pictures that have been shown in international exhibitions of the plastic arts, among them Nidā' Khūrī, Jamāna 'Abbūd, Natalie 'Adnān and others. A number of contemporary poets, especially in Morocco and Algeria, printed their poetry collections with a view to maintaining the rhetoric of geographical space in order to create meaning. Thus, for example, we may mention 'Izz al-Dīn Mayhūbī's poetry collection Mulșaqāt (Placards; fig. 5), 'Āmir Shārif's alZ̦ama' al- 'ātī (Raging Thirst), Yūsuf wa Ghalīsī's Awjā' șafșāfa fĩ mawsim al-i șār (The Willow's Pain in the Storm Season; fig. 6) and al-Akhḍar Shawādir's Shubhāt alma'nā (Uncertain Meanings). 
Fig. 5 - The poem "Fāji 'a" ("Misfortune"), from 'Izz al-Dīn Mayhūbī's poetry collection Mulṣaqāt (Placards)

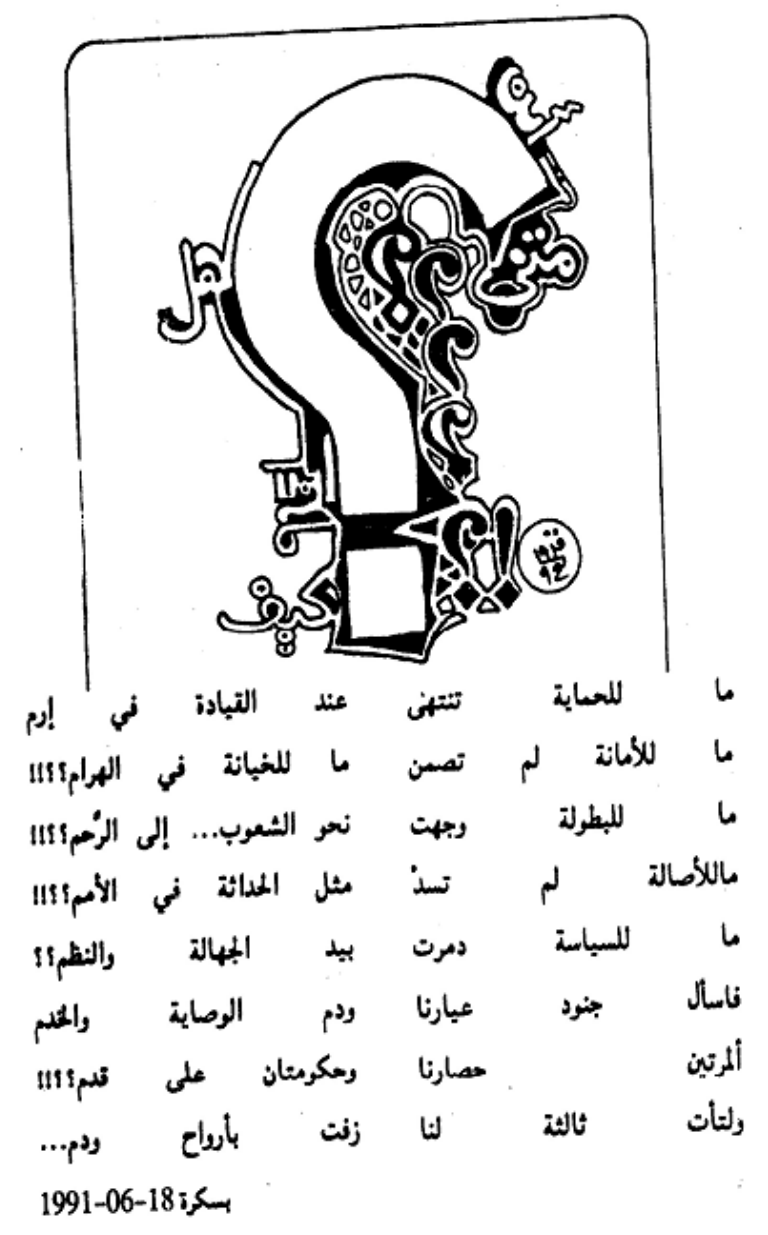


Fig. 6 - The poem "Āh yā wațan al-awțān" ("Oh Homeland of Homelands), from Yūsuf wa Ghalīsī's Awjā' șafșāfa fi mawsim al-i 'șār (The Willow's Pain in the Storm Season)

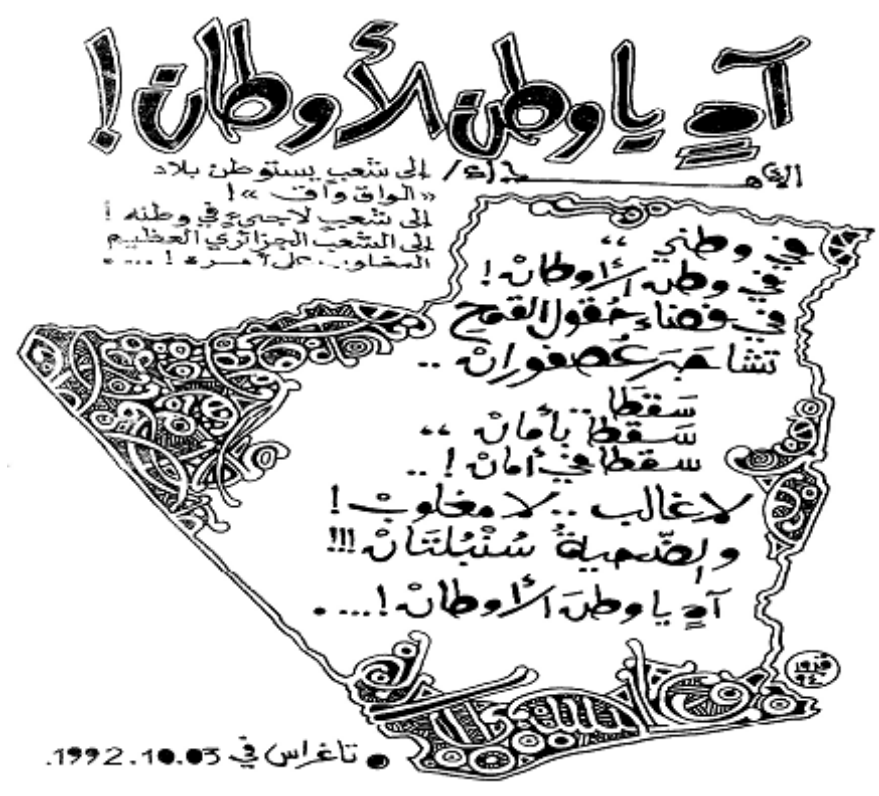

These poetry collections are special in that their poetic rhetoric is not limited to morphology, syntax, semantics and metrics, but encompasses every aspect of the written text, including script and print, and non-linguistic signs. The poems in these collections are silence and sound, black and white. The accompanying drawings have their own meanings, as do the form of the script and the text's position on the paper. All these elements operate together with language to generate distinct meanings which the reader perceives also through his sense of sight, in an attempt to understand the poem's formal levels and reveal the semantic relationships among all its symbols (KHARFī, 2014).

Visual poems thus possess two basic elements, form and content, and must be read in a way that moves from form to content and vice versa. Modern literary critics have discussed the rhetorical connection between these two elements. In his book Shakl al-qașida al-'arabiyya (The Form of the Arabic Poem; 1984) the critic Jawdat Fakhr al-Dīn presents a number of modern Western theories on poetic form and its relationship with content. He discusses the metaphysical approach, according to which form precedes matter, as argued by Ernest Fisher in his The Necessity of Art, who declared that everything in the world consists of form and matter, and the more 
form dominates the weaker the resistance of matter and the greater the value of the realized perfection (Fakhr al-Dīn, 1984, p. 168). This fits in with Gestalt theory, according to which the whole precedes the part. This means that a poem's structure gains mastery over the receiver's eye before he perceives the details and components of that structure, because the structure possesses various messages and meanings that are no less important and no less influential for the receiver than the messages borne by the words.

The Moroccan writer Muḥammad al-Mākrī in his book al-Shakl wal-khițāb (Form and Speech; 1991) noted the importance of visual form in poetry as a rhetorical element. He stressed the significance of artistic staging in Arabic poetry and the way in which a single text is produced through the intertwining of two structures made of two distinct expressive sequences. In other words, poetry consists of a search for formulations in which the "visual" form becomes united with the "linguistic" speech, by way of what he calls the treatment of "spatial engagement" in the text. By the term "spatial engagement" (al-ishtighāl al-faḍāî̀) he means the sum total of "spaceforming" phenomena in the presentation of written poetic texts, or the data derived from the written or printed form of the text. In his words, "this spatial element, despite its clearly secondary nature, can generate meanings in the text, because it is neither neutral nor silent, even in texts whose production is not dominated by the functional intentionality of turning their space into a poetic element" (AL-MĀKRT̄, 1991, p. 5).

Al-Mākrī defines two types of space in visual poetry:

1. Textual space, which contains the written denotation, so that what is presented within its framework remains merely a text presented for reading.

2. Figural space, which contrasts with the previously mentioned space but also complements it. This is because what we perceive we read visually and not as a text, and within it there is thickness and a formational difference which is not read but seen. It is what is given to sight inside the text that constitutes its figural space, while the textual space is what is given to reading (ibid., pp. 233-241). 
This means that textual space gives primacy to the eye, which has the function of reading and scanning the written text, while the components of figural space cause that sending operation to cease and require a longer time period for perception (ibid., p. 242).

We may conclude from the preceding discussion that the visual dimension of a poem and its external form is an issue that has attracted the attention of both critics and poets, because of its importance as an esthetic and semantic value in the text and its effect on the receiver, at a time when only the simplest writing utensils existed, ink and paper, which is one of the reasons why the possibilities for the creation of figural space in visual poems on paper were quite limited, as we noted above. In fact, the possibilities were limited to the way black was distributed over white, that is, the way in which words were written and spread on the page. The most that poets could do was to play with the type of script, the order of the words on the paper, and to add some sketches, which in general were also in black-and-white.

\section{From visual to digital rhetoric}

The artist and poet Roy Scott says that the recent years have witnessed the emergence of two computer-related technological powers, namely line and wireless communications, which have made it possible to interconnect more than one communication medium, for example video art, acoustic installations, remote communications and cybernetics. This has had a great influence of society and on individual behavior and has raised questions concerning the nature of man and the nature of creativity. The truth of the matter is that our relationship with each other and with our world in general has become ever more closely related to the network culture that is synchronized with ever more new inventions that have led to the rise of behavioral and intellectual systems and social values that are unlike those that have become institutionalized since the Enlightenment movement. Cultural borrowings and new scientific models have been introduced, with which representations of reality and expressions of it could be fabricated (SCOTT, 1990). 
Since Scott published his article in 1990 computers and social networks have evolved very rapidly, as a continuation of a long historical developmental path from the industrial revolution to this day, a path that consists of at least two centuries of experimentation and change, until the arrival of what has been called virtual reality. This is the reality which modern societies experience, thanks to the computer, digital networks and the dominance of satellite television. The internet, the cellular phone, the tablet, video and audio files, all bind humankind to instruments, which are used in all fields of creative activity, including art and literature.

The term "digital rhetoric" has come to express this new techno-human relationship. According to Zappen this term is connected to virtual reality and virtual society. This makes it broad enough to encompass numerous concepts derived from various domains, such as sociology, psychology, the natural sciences and the arts. $\mathrm{He}$ maintains that the social networks have created a new climate that enables people from all countries, nationalities and faiths to interact together, to exchange views and knowledge, to share data, to express themselves freely, to do original work, and to work together towards the creation of virtual societies possessing common fields of interest. This is made possible by various technical devices for expressing oneself, using voice, pictures, video and the like. This has led Zappen to propose the creation of a new integrative theory of rhetoric, one that would be able to assimilate concepts from every science (ZAPPEN, 2005).

However, in the present study we shall not deal with the term "digital rhetoric" in the broad sense in which it is used by Zappen. Here we shall restrict ourselves to the literary aspect only. The great technological developments that changed the field of communication during the last half of the previous century, especially the computer and programming, have led to the appearance of new techniques that proved useful to writers. These include new methods of expression, in addition to words, such as multimedia and hypertext. 
This cross-fertilization between literature and technology brought about a change in the features of the familiar literary genres, which can to possess both literary and technological features. Digital poetry is one of these hybrid genres.

According to Roberto Simanowski digital poetry crosses over from the verbal to the digital level. He argues that the technological features must support the linguistic ones (SIMANOWSKI, 2010, p. 17). This is the digital rhetoric that we have in mind in the present study.

A number of scholars who have undertaken an analysis of digital texts using computerized techniques, among them Alan Sondheim, John Caylay, Katherine Hayles, Rita Raley, Florian Kramer, Giovanna Di Rosario, Roberto Simanowski, Adalaide Morris, Loss Pequeño Glazier and others, agree that a digital poem is:

\begin{abstract}
A type of poetic writing that appears only over electronic media, based on techniques which modern technology makes available and taking advantage of the various electronic devices, in order to create various types of poetic texts that differ in their style and in the way they are presented to the receiver, who can only find them on the screen and deal with them electronically, whether by interaction, addition or participation (NAȘRALLĀH \& YŪNUS, 2014).
\end{abstract}

Visual digital poetry in Arabic appeared in the first decade of the third millennium. The pioneer in this field was the Moroccan poet Mun im al-Azraq, who published a number of digital texts on the al-Mirsāh ("The Anchor") website2. The number of Arab poets who have produced poetry using a digital medium is still very small compared to the Western world. Among Arab digital poets we may mention Mushtāq 'Abbas Ma'an from Iraq, Sūlārā al-Ṣabāḥ from Syria and 'Abd al-Nūr Idrīs from Morocco.

The use of high-tech techniques in original writing has also led to changes in many of the commonly accepted terms and concepts used in modern critical theories and schools of thought. One of these concepts is "rhetoric" (balāgha), which has come to be evaluated using innovative criteria and tools. The word alone is now no longer considered the sole material of the text and its spirit, nor is the way in which black is spread unto white, for today writers have access to additional means of expression. 
Color, for example, can by used as a symbol, movement as meaning, music as allusion and picture as metaphor. The technique of hypertext has enable writers to link their texts to others and so create a mosaic in which many different texts intertwine and interact, in what has become known as "hybrid texts". Some critics have gone even further and called it "archiart", in which all the different kinds of art interact: music, film direction, painting and drama.

Simanowski argues that this kind of writing has taken the text out of the sphere of literature into a more inclusive and comprehensive domain, that of art, and so digital literature has become one of the branches of digital art (SIMANOWSKI, 2010, p. 17). This means that digital rhetoric has opened new horizons for texts; literary texts are no longer produced only for reading, but also with the intention that they be seen, watched and heard.

\title{
Elements of digital rhetoric
}

Critic Jāsim Bāqir states:

\begin{abstract}
The digital poem is not merely a verbal text to which pictures and musical passages have been added. Rather, it is a text made up of all these element, taken as components that exist side by side and that possess an equal importance. The verbal text has become just one among a number of constitutive elements. This kind of composition, which aims at athe creation of a distinct intellectual and esthetic effect, requires a different esthetic sense of taste, which can be enhanced through technologies that play a vital role in the operations of both composition and receptions, while keeping in sight the ultimate esthetic objective (BĀQIR, 2009).
\end{abstract}

In light of the above, when we speak of the elements of digital rhetoric we refer to the visual and acoustic signs that accompany the word, as indicators and bearers of meaning that are directed towards the operation of reception and affect it.

These elements are the following:

- Textual space

The most obvious difference between visual poetry on paper and visual poetry in digital form is the nature of their textual space. While the words of a paper poem are 
distributed over a white sheet of paper, the words of a visual poem are spread throughout the space of the screen itself. The latter is a space that can have a threedimensional aspect using the technique of the hypertext, so that the reader can read not only from right to left or from top to bottom as in traditional reading, but rather from front to back and from the surface into the depth.

On this issue Janez Strehovec says that the reader must interact with the words and sentences of a digital text taking not only its linguistic contexts into account, but also its positioning on the screen. He must reflect on the meaning of these positions, since pictures and linguistic texts are placed in a certain way on the screen by the writer in order to convey a certain intention. Spatial rhetoric in a digital text resides in its depth and in the meaning of this depth, as opposed to the superficiality of the traditional text (STREHOVEC, 2010, p. 207).

In Mun'im al-Azraq's poem "Shajar al-būghāz" ("The Trees of the Harbor"), for example, the poet distributed the linguistic texts and the pictures throughout the screen space for semantic effect. The pictures are occasionally positioned in the middle but may also appear on the top left or on the bottom right side, and the same is true of the linguistic text (fig. 7). 
Fig. 7 - From Mun 'im al-Azraq's poem "Shajar al-būghāz" ("The Trees of the Harbor").

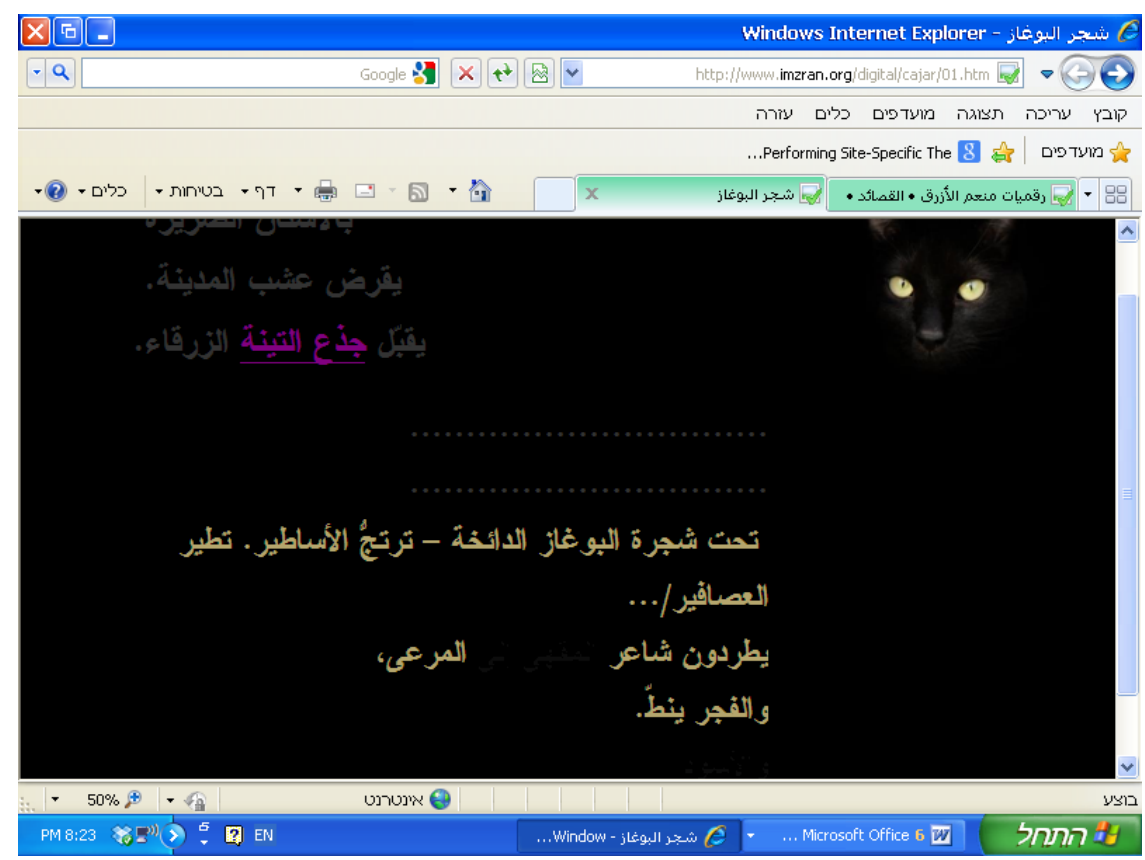

\section{- Colors}

Colors are used for stressing a certain situation or value, by drawing the receiver's attention to the symbolic significance evoked by the color. If the creator of the work in question uses a color that differs from the object's color in real life, for example by making the sky green instead of blue, this deviation from the natural color can be understood as part of the scene's color symbolism. In general, colors can be divided into two groups, cold colors that give rise to a feeling of peace and quiet, and warm colors that arouse on to work, activity and vitality. Thus the use of a particular color of necessity symbolizes or evokes a certain meaning or reflects a distinct meaning which the reader must discover (NAṢRALLĀH \& YŪNUS, forthcoming).

\section{- $\quad$ Printed form}

By "printed form" we mean the way words can be played with by manipulating their size, the thickness of the script, their division and order, and their appearance in the textual space. The script is one of the most prominent visual factors in digital poetry. It is worth noting that in the second half of the last century some contemporary semiotic approaches to criticism began to deal with the typographical aspects of works of literature and the printed forms of the script. 
Al-Mākrī argues that different versions of a poetic text can differ with respect to the size and shape of the letters and the thickness of the lines. This phenomenon can be considered as a stylistic indicator, or a visual written way of stressing a stanza, a verse, a lexical entry or a written unit. From this perspective its suggestive role is almost like that which is played by stress in a verbal execution of a text. Al-Mākrī adds:

\begin{abstract}
The technical advances in the audio sphere have helped to create new possibilities for creative writing through the poetic exploitation of various languages that possess an exciting acoustic value, to create acoustic scenes with words and syllables, sounds and silences, every type of intertwined linguistic fields. Words are then transformed into charges by way of the creation of regions of attraction among the various component elements by focusing on the energy that is latent in linguistic cells. Enlarging a letter or a word adds a guided acoustic value or an acoustic meaning in the course of reading (AL-MĀKRT̄, 2001).
\end{abstract}

This is the conclusion to which David Crystal also came in his study on the language of the internet. He found that the script possesses a significant acoustic value, which can be exploited by the author of any internet text in order to express his own voice through the manipulation of the size of the letters, their divisions, their colors and more (Crystal, 2001, p. 35). The manipulated letter size stands for different sound levels; thus bold letters stand for a loud voice while thin letters stand for a more quiet voice.

While it is true that the manipulation of letters appeared already at the very outset in visual poetry, but technological progress has opened more opportunities for poets, who have come to type out their texts by themselves and to manipulate the letters' form, color, typeface, size and thickness, in the service of meaning. One digital poet in which the script plays an important role is Mun im al-Azraq's "al-Danw min al-hajj al-dā'irī" ("Approaching the Circular Pilgrimage") (fig. 8). 
Fig. 8 - Mun 'im al-Azraq's poem "al-Danw min al-ḥajj al-dā' ir̄̄" ("Approaching the Circular Pilgrimage").

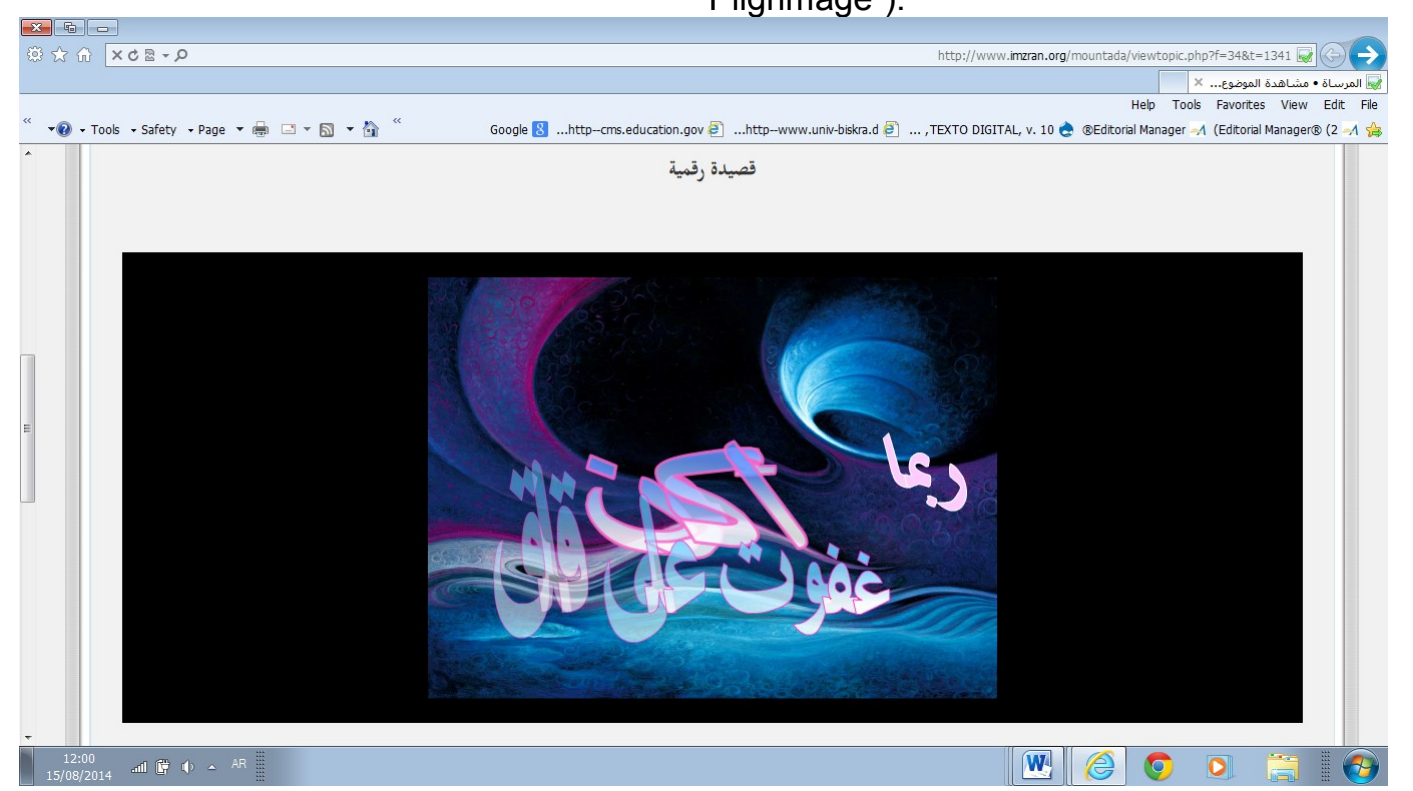

- Motion

Motion is a visual element that is present only in digital literature, since it cannot possibly be a part of traditional paper texts, except metaphorically. Motion is an important element, especially in visual poetry. It appears as such in most of Mun im al-Azraq's poems, such as "Sayyidat al-mā'" ("Mistress of the Water") (fig. 9), in which the use of the element of motion makes a number of different readings of the poem possible.

Fig. 9 - From Mun'im al-Azraq's poem "Sayyidat al-mā'" ("Mistress of the Water").

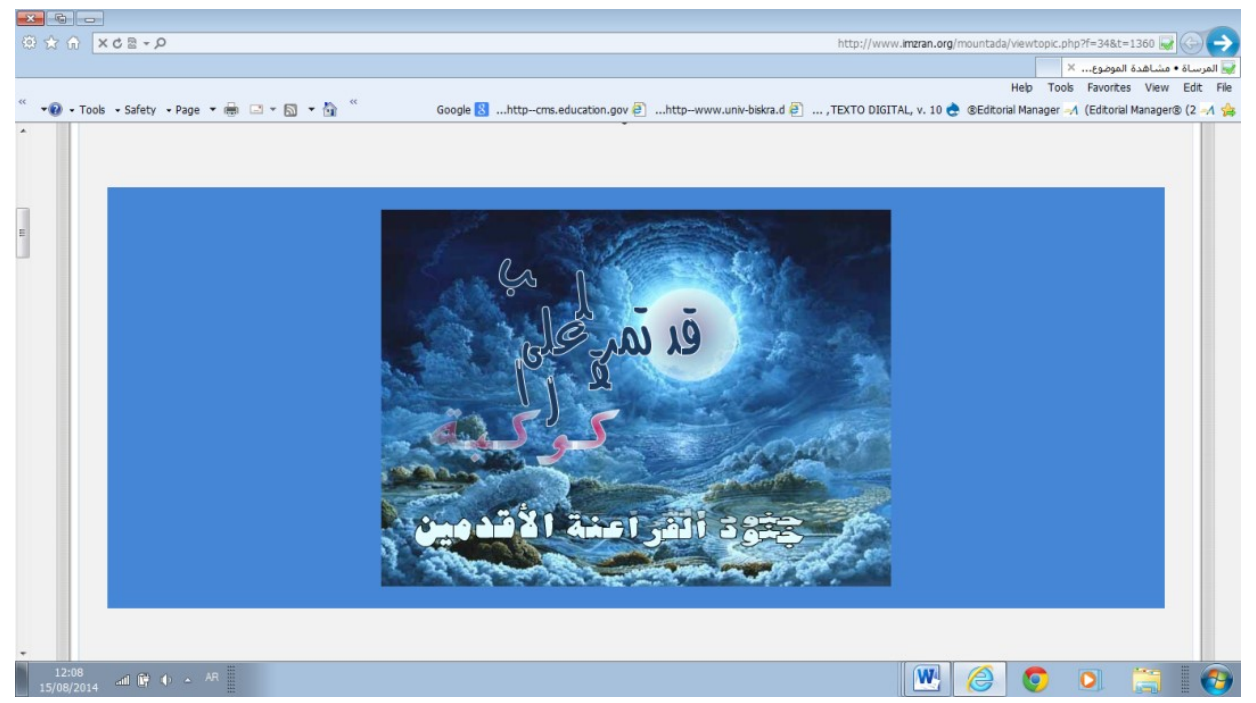

Texto Digital, Florianópolis, Santa Catarina, Brasil, v. 11, n. 1, p. 118-145, jan./jun. 2015. ISSNe: 1807-9288. 
The most important change that has occurred in digital poetry in general, after the introduction of techniques for adding motion, is the collapse of the poem's locational and geometrical structure. A poem printed on paper has a very clearly delineated geometrical structure, that is, it has a specific form, dictated by the way the black is distributed over the white or the words are distributed over the page. In the age of traditional poetry the term "whiteness and blackness" enjoyed great popularity among critics. From a poetic perspective the black areas or the areas covered with text were perceived as areas of speech, while the white areas marked pauses or moments of silence.

But although this depiction fits the situation with respect to a text on paper, it can hardly be applied to digital texts, in which lines are not fixed, and so blanks or white spaces do not of necessity imply moments of silence. The black filling (the words), too, no longer stand for long or short affective gusts, as was the case in poetry on paper. Things have become much more complex, for on a computer it is possible to observe widely different forms in a single text in the form of a tide, so that the inside of a single textual space can have multiple different relationships among the two regions. These relationships basically go back to the nature of the programming activities in which the writer engages in order to construct his own mental space, which he then reflects unto the textual space.

The term "blackness and whiteness" is thus rather inappropriate for digital poetry, because of the countless colors that are available and because the old concept behind this term no longer has any meaning. Digital poetry use the screen's hypothetical area in order to distribute his text as he sees fit, using the elements of motion and print formation for this purpose. In some digital poems the lines are in the upper part, in some they are in the middle, in others they are on the left side and in still others on the right side. Furthermore, the words themselves are no longer fixed in place; a word or a line can change place or disappear, so that the "whiteness" is no longer fixed. The empty spaces are no longer stable, as they were on paper, and therefore digital poems do not have a fixed form, since they possess motion. The form of this motion, which can be circular, spiral or undulating, and its direction, are 
connected to the poem and its meaning, and are therefore important rhetorical elements in digital poetry.

- Images

An image has an esthetic or metaphorical role in addition to its ability to serve as a means of communicating with the receiver in the sense that it can be talked about. But in digital literature or poetry the image has become a medium that interacts among the various other media mentioned above, and is used by poets as a factor in the text's comprehension.

Different images have a greater or a lesser ability to create such an interaction with the receiver, just as different readers differ in their ability to understand it, depending on their awareness and education. Some images have an esthetic dimension which arouses multiple readings and effects in the reader. These readings, despite their different backgrounds, remain to a large extent in thrall to considerations in which the receiving self is interconnected dialectically with the topic to be received. Reception and interpretation are basically intertwined and present to us the problematics of the exegetical canons which derive their authority from social, ethical and esthetic values. Images in general are inert, but they immediately become alive when interpreted, and as a result the reading of one and the same image can differ in different contexts (NAṢRALLĀH \& YŪNUS, 2015).

Sonja Foss argues that every image has two aspects. The material aspect is associated with the actual elements that constitute it, such as color and size, while the abstract aspect deals with the meanings that the image conveys. From this she concludes that was is important in an image is not what is present (its material facet) but rather what is absent in it (the abstract aspect). It is the latter aspect which depends on the receiver's level for its perception (FOSS, 2011).

Shākir La'ībī in his book Balāghat al-lugha al-īqūniyya (The Rhetoric of Iconic Language; 2008) states that an image affords a much wider range for interpretation than language, because the former only very rarely imposes a single meaning, while 
that is precisely the usual case with spoken expression. The term "polysemy" is thus associated with images or icons, which must therefore be dealt with in a mature critical manner, enabling the receiver to sift through the various expected meanings and choose the meaning or meanings intended by the image in a specific literary context (LA'T̄BT̄, 2008).

In Mushtāq 'Abbās Ma'an's poem "Tabārīḥ raqamiyys li-sīra ba ọ̣hā aqraq" ("Digital Agonies of a Biography Part of Which is Blue"), for example, many images are used as semiotic signs in a variety of contexts. The images are taken from legends and from Western art, and turn the poem into a work in which the plastic and the verbal arts are intertwined (fig. 10).

Fig. 10 - From Mushtāq 'Abbās Ma'an's poem "Tabārīḥ raqamiyys li-sīra ba 'ḍhā aqraq" ("Digital Agonies of a Biography Part of Which is Blue")

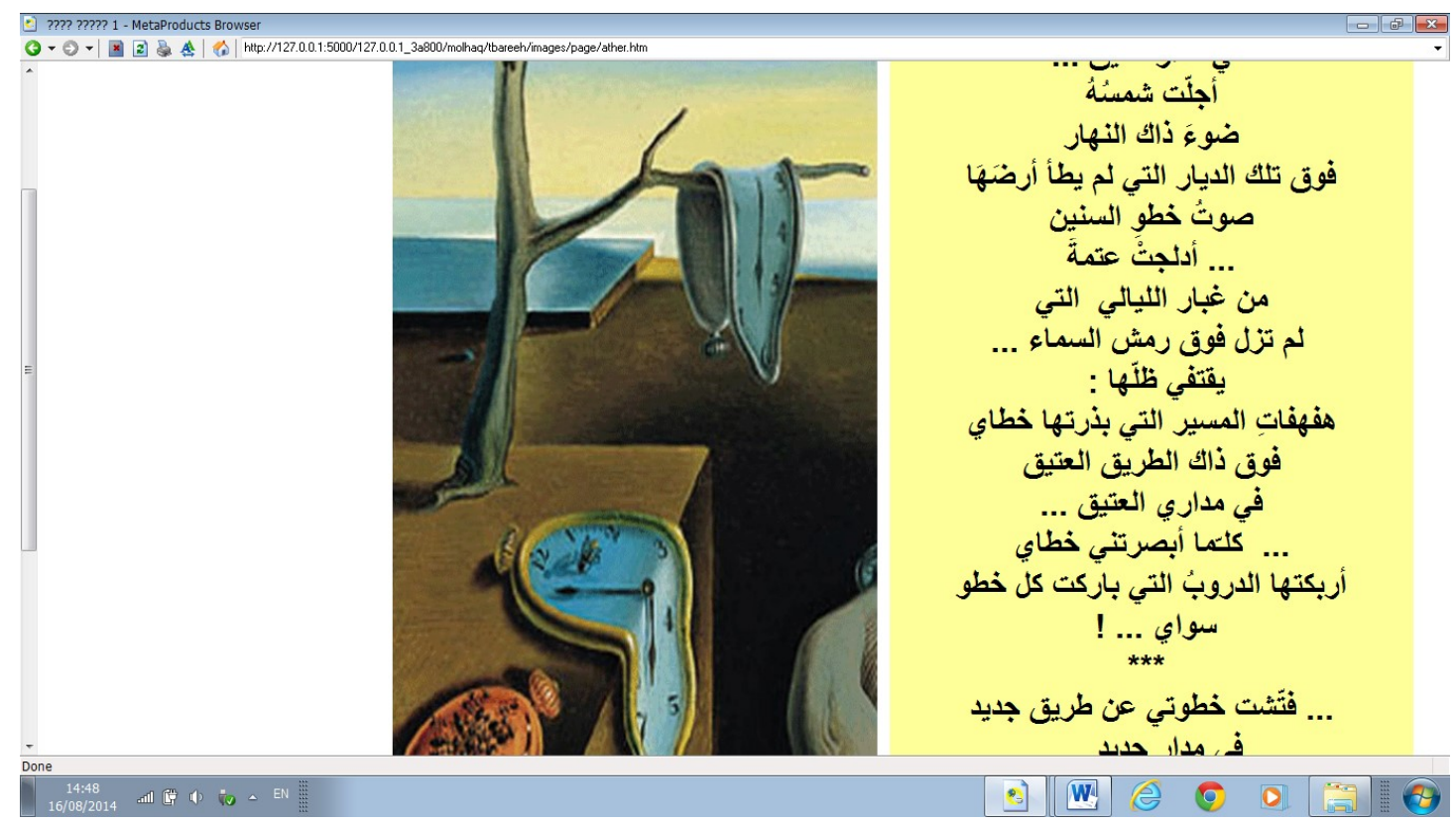

Sound and music

The use of acoustic elements occurs exclusively in digital texts and these, like other elements, are the carriers of specific messages and meanings. A writer may combine more than a single type of music in one work of literature, as is the case in the poem "Tabārīḥ raqamiyys li-sīra ba ḍuhā aqraq" ("Digital Agonies of a Biography Part of Which is Blue") mentioned above, where the poet combines Western with Arab, 
romantic with revolutionary nationalist music, in the form of a poetic painting in which the music, the paintings and the words are in harmony with each other.

\section{Connections}

The use of hypertext techniques has led to very great changes in the nature of literary texts. The aforementioned techniques have disrupted texts, not only with respect to the direction in which they are read, but also in their contents and the types of art which they contain. As a result Muhammad al-Mas 'ũdī has coined the term balāghat al-matāha ("rhetoric of the maze") for the kind of rhetoric generated by hypertext techniques, because they bring about a coalescence of the personal with the collective, the calligraphic with the photographic and the visual, motion with acoustics, and so on (AL-MAS 'ŪDĪ, 2013).

The elements of digital rhetoric are thus present in the digital text through color, image, script, motion and music, each of which plays an important role in the creation and manifestation of the meaning. They are closely connected to the meaning and participate in its derivation, in addition to giving the text an esthetic dimension which is absent in the tradition works on paper. The receiver must penetrate into the relationship among all these elements, reveal their semantic and symbolic connections and dimensions, and comprehend their mutual symbolic and philosophical dependencies. This is one of the great challenges which digital rhetoric poses to the text.

Consequently, while the esthetics of a traditional text are realized through its departure from the familiar using sanctioned rhetorical styles, the departure of digital texts from the accepted and familiar is realized through the multiplicity of media it contains, which open it to an infinitude of readings (STREHOVEC, 2010, pp. 211 212). This requires of critics who discuss digital poetry that they use the method of semiotic analysis and violate the linguistic order in an attempt to form a new order with its own characteristics and style (DI ROSARIO, 2011, p. 80). This has the effect of generating multiple interpretations of a poem, at times even interpretations that are mutually contradictory, with the result that it becomes impossible to arrive at a single 
meaning or a definitive and absolute intention for digital works of literature. In fact, the concept of arriving at a meaning is no longer an objective which the receiver strives to realize; rather, the desired objective now comes to be the reader's participation in the very production or restructuring of the text.

According to Wardrip-Fruin there are two important aspects which critics must take into account in order to determine the esthetics of a digital text:

1. Data (the elements which make up the text, such as images, colors, script, etc., and the way these are distributed and designed);

2. Process (the operating plan and software on which the text is based) (WARDRIPFRUIN, 2010, p. 37).

As a result, while modern programs of criticism have re-read visual poetry in light of their behavior in accordance with the habits and laws of visual rhetoric, we are still in dire need of a new type of literary criticism that would on the one hand take into consideration all the changes that have occurred in the various literary genres due to their adoption of the norms of digital rhetoric and, on the other hand, deal also with the computer-generated art on which these digital texts are based, what has become known as "software art". In order to do this we must institutionalize a new concept of the science of rhetoric.

Contemporary digital literature has been discussed by a large number of critics in the West, as well as a number of critics in the Arab world, such as Muhammad Aslīm, Fāța al-Barīka and Ibrāhīm Milḥam. These critics tried to clarify the features of this literature and to deal with the changes that texts have undergone as they were transferred from paper to a digital medium, and the changes in the concepts of text, reader and writer as a result of this transition. However, they do not use the term "rhetoric" in its technical sense; rather, they refer to it only implicitly when they discuss the semiotics of digital texts, so that the term has so far remained blurred and has not been the subject of enough profound discussion. 
Lastly we must note that digital rhetoric is present in our everyday lives, not only in literature but everywhere and in every domain: on television, in commercials and on billboard advertisements. In order for the individual to be able to cope with the data of digital rhetoric we must raise a new generation possessing a comprehensive education and critical tools from different spheres of knowledge. This is the responsibility of academic institutions and the school system.

\section{Conclusion}

The conclusion at which we arrived in this study is that the rhetorical dimension of the visual formation in Arabic poetry of the Mamluk period only received the attention it deserves after the emergence of artistic currents and movements in the West, especially during the Baroque period. The critical movements that examined visual formation as a rhetorical vehicle, such as Dadaism and Cubism, emerged after World War I. Arab critics were influenced by these movements and adopted their ideas in order to analyze Arabic literary texts. They demonstrated the rhetorical value of visual poetic texts, both ancient and modern, and treated classical Arabic poems as works in which form and content were inseparable. They argued that the external esthetic value of the visual dimension that pleases the eye is not less than the semantic value, and that both are basic components of rhetoric.

With the emergence of digital visual poetry rhetoric came to encompass the new elements created by technology. A poet's rhetoric became dependent on his ability to use these elements, such as color, motion, music, links, etc., in the service of the text's meaning, providing the receiver with new forms with which to interact. Both writer and reader are thus required to possess critical tools belonging to multiple domains.

This leads us to infer that the basic function of visual rhetoric, which is to affect the receiver, has not changed at all over the ages, despite the changes in the phenomenologies of the visual text from the Mamluk period to the digital age, since what has changed was only the technique. This proves that the phenomenon of 
digital literature does not constitute a break with literature, but rather an evolution. The new digital rhetoric is one that is broader and more comprehensive, and we are therefore in need of formulating a new comprehensive theory that can exploit what contemporary theories have made available while taking account of all the changes that literary texts have undergone as a result of their impregnation with technology. In this study I have attempted to prepare the way for inculcating the term "digital rhetoric" into digital literary criticism, to determine its identity and to remove of the obscurity surrounding it, in the full realization that we are still at the beginning and that we have a long way to go.

\section{A RETÓRICA NA POESIA ÁRABE VISUAL: DO PERÍODO MAMELUCO À ERA DIGITAL}

RESUMO: O presente estudo concentra-se nas manifestações da retórica visual na poesia árabe visual e na forma como a crítica literária tem lidado com isso. A poesia visual, como é conhecida nas ciências literárias, refere-se aos aspectos da poesia, que vão além da linguagem e do conteúdo, como uma forma básica de poemas e de estrutura externa. Estas manifestações retóricas são derivadas a partir da relação entre forma e conteúdo, de modo a gerar significado e afetar o leitor. O presente estudo concentrar-se-á nas manifestações da retórica visual na poesia visual árabe e na sua evolução, do período mameluco até a era digital.

PALAVRAS-CHAVE: Retórica visual. Poesia visual. Poesia digital. Retórica digitais.

\section{References in Arabic}

ABŪ DĪB. Jamāliyyāt al-tajāwur aw tashābuk al-faḍā'āt al-ibdā 'iyya (Esthetics of Adjacency or the Interconnection of Creative Spaces), Beirut: Dār al-'ilm lil-malāyīn, 1997.

ABŪ KHADQRA, Fahd. Al-Tawāfuq al-lafẓi (Verbal Harmonization). Nazareth: Mu'assasat al-mawākib, 2007.

ADONIS. Zaman al-shi 'r (The Time of Poetry), Beirut: Dār al-'awda, 1978.

BANYAS, MUHAMMAD. Z̄āhirat al-shi 'r al-mu'āșir fĩ al-Maghrib, muqārana banywiyya takwiniyya (The Phenomenon of Contemporary Poetry in Morocco, a Structuralist Existentialist Comparison), Morocco: Dār al-tanwīr lil-țibā'a wal-nashr, 1985.

BĀQIR, JĀSIM. 2009. Mutūn mutajāwira mutashābika: al-shi'r min al-samā' walqirā'a ilā al-tafā ul, dirāsāt (Adjacent Neighboring Texts: Poetry from Hearing and Reading to Interactivity, Studies). Bābil University, al-Jumhūriyya, pp. 34-39. Last 
access August 8, 2014, URL:

<http://www.algomhoriah.net/newsweekarticle.php?sid=97847>.

FAKHR AL-DĪN, Jawdat. Shakl al-qașida al- 'arabiyya (The Form of the Arabic Qașìda), Beirut: Dār al-ādāb, 1984.

HUSAYN, FĀḌIL YŪNUS. 2012. Jamāliyyat al-qașīda al-handasiyya bayna al-wāqi wal-țumūḥ: dirāsa istiqrā'iyya wa-tațbīqiyya (The Esthetics of the Geometrical Poem between Reality and Aspiration: An Investigative and Applied Study). Journal of the College for Islamic Studies, 6(12), pp. 1-58. Last access August 1, 2014, URL: $<$ www.iasj.net/iasj?func=fulltext\&ald=61858>.

KHARFĪ, MUHAMMAD AL-ṢĀLIḤ. 2014. Al-Talaqqī al-bașrī lil-shi r: namādhij shi riyya jazā'iriyya mu'āșira (). The 5th International Colloquium on Semiotics and Literary Texts, Jejel University, pp. 540-562. Last access June 15, 2014, URL: <http://lab.univ-biskra.dz/lla/images/pdf/sem5/kharfi.pdf>.

LA 'T̄BĪ, SHĀKIR. Balāghat al-lugha al-īqūniyya - al-șūra bi-wașfihā balāgha (The Rhetoric of Iconic Language: Image as Rhetoric), Baghdad: Kitāb al-Ṣabāḥ al-thaqāfĩ (series), 2008.

AL-MĀKRT̄, Muḥammad. Al-Shakl wal-khițāb, madkhal li-taḥlī żāhirātī (Form and Speech: an Introduction to a Phenomenological Analysis). Casablanca: al-Markaz althaqāfī al-'arabī, 1001.

AL-MAS 'ŪDĪ, Muhammad. Min al-nass al-waraqī ilā al-nașș al-tafā ūlī: balāghat altașwīr al-fannī fī "Tābārīḥ raqamiyya li-sīra ba 'ọuhā azraq" li-Mushtāq 'Abbās Ma 'an (From Paper Text to Interactive Text: The Rhetoric of Artistic Imagery in Mushtāq 'Abbās Ma'an's "Digital Agonies of a Biography Part of Which Is Blue"), Union of Arab Internet Authors, 2013. Last access May 14, 2014, URL: <http://www.arabewriters.com/data.php?topicld=15>.

NAȘRALLĀH, 'Āyida \& Yūnus, E. al-Tafā 'ul al-fannī al-adabī fĩ al-shi 'r al-raqmī: qașīdat "Shajar al-būghāz" namūdhajan (Artistic Literary Interaction in Digital Poetry, "The Trees of the Harbor" as an Example). Amman: Dār al-shurūq lil-țibā'a walnashr, 2014.

AL-TALĀWĪ, Muḥammad Najīb. Al-Qașīda al-tashkīliyya fĩ al-shi 'r al- 'arabī (The Visual Qașida in Arabic Poetry), Cairo: al-Hay'a al-mișriyya al- āmma, 1998.

AL-WARĀRT̄, 'Abd al-Lațīf. Al-Shi'r al-bașarī 'inda al- 'arab (Visual Poetry among the Arabs), al-Hurūf. Last access August 14, 2014, URL:

<http://www.horoof.hautetfort.com>.

\section{References in English}


CRYSTAL, David, Language and the Internet, New York: Cambridge University press, 2001.

DI ROSARIO, Giovanna. Electronic Poetry: Understanding Poetry in the Digital Environment, Jyvaskyla: University of Jyväskylä Press, 2011.

FOSS, Sonja. Theory of Visual Rhetoric, Defining Visual Rhetoric, London: University of Wisconsin Oshkosh, 2011.

SCOTT, Roy (1990). in Art Journal, (fall):242-247.

SIMANOWSKI, Roberto. Reading Digital Literature: a Subject Between Media and Methods, Reading Moving Letters, London: New Brunswick, 2010.

STREHOVEC, Janez. Digital Poetry and the Realm of Language, Reading Moving Letters, London: New Brunswick, 2010.

WARDRIP-FRUIN, Noah, Five Elements of Digital Literature, Reading Moving Letters, London: New Brunswick, 2010.

ZAPPEN, James. 2005. Digital Rhetoric: Toward an Integrated Theory, Technical Communication Quarterly, pp. 319-325. Last access July 22, 2014, URL:

$<$ http://gossettpfd/library/zappen_digirhet.pdf>. 